An Empirical investigation into the Risk Management Strategies of MFIs in Cameroon

\begin{abstract}
:
This paper examines risk strategies adopted by MFIs in Cameroon Much research on risk and especially after the financial crisis of 2007 has been based on mainstream financial institutions and ignored the contribution of risk on MFIs activities and in our societies. This study is based on 15 in depth interviews with 7 managers and 8 lending officers, we identified four main areas of risk concerns for MFIs in Cameroon; reputational, death of a borrower, credit and institutional size risks. Our results show that risk is an elusive concept for which we cannot understand or measure the effect on an organisation. So as to help minimise these effects, we propose MFIs to take the for-profit status in order to attract investors who are willing to invest within MFIs, therefore minimising the effect of risks on MFIs.
\end{abstract}

Keywords:

Microfinance, Risk Management Strategy, Cameroon 


\section{An Empirical investigation into the Risk Management Strategies of MFIs in Cameroon}

\section{Introduction}

Microfinance is a risky business. It is risky by virtue of the nature of its clientele who in majority are made of the "bankless", the poor and people with little or no collateral and consequently are unable to get loans from main stream financial institutions (Brau \& Woller, 2004, Akanga, 2017). This leaves us with a situation where financial institutions face the risk of default on loans thereby putting clients' savings at risk. Microfinance Finance Institutions (MFIs) like many other financial institutions, faces similar type of risks (Berenbach \& Chruchill, 1997). Unlike financial institutions, MFIs have to manage their risks efficiently and effectively in order to meet their social and financial objectives (Steinwand, 2000). When MFIs issue loans, there is that risk of a borrower defaulting on the loan. This growing concern about default from borrowers shows a fundamental shift among bank managers and regulators.

As Mikes (2011) predicted, this growing concern follows lessons learned from the debacle of the financial crisis where none of the victims of the financial crisis had a risk management officer. As a result, organisations have not only appointed risk managers and officers within their organisations but have explicitly related risk mitigation and management to their organisational and sub - organisational objectives (Power, 2009). This has seen organisations "identify all material risks to their objectives and sub-objectives, design controls and mitigations" (Power, 2009: 849) with the aim of producing manuals that will help them produce framework consistent with their risk appetite and for which they can use to monitor the whole risk processes their organisation is involved in. The whole idea is to make sure that good risk management practices should lead to a system of managerial innovation that allow managers to use their scarce resources to create "market opportunities" (Beck, 1992) and also make sure that mistakes of the past are mitigated (Power, 2009).

Increasingly, managing risks has become an important component of many financial institutions. If poorly managed, this might lead to loss of customer confidence, loss of financial resources, donors, investors, lenders and borrowers consequently; the financial institution will go out of business (Goldberg \& Palladini, 2010). However, many risk features of financial institutions are not directly related to the MFIs. Some of these risks are awarding large loans to a single borrower that can put the total bank's capital at risk, awarding multiple large loans that can put the whole enterprise capital at risk or where managers and owners can use their influence to award loans of significant size to borrowers (Berenbach \& 
Chruchill, 1997, Akanga, 2016). In the case of MFIs, they are hardly exposed to same risks as financial institutions becase their loan sizes are usually small and in smaller volumes (Berenbach \& Chruchill, 1997, Hermes et al., 2011). It is for these reasons that Berenbach \& Chruchill (1997) and Steinwand (2000) argue that, any framework designed to manage risks within MFIs should be different and based on an understanding of the risk features within MFIs so as to effectively manage these risks. This paper therefore makes two contributions. Firstly, we make a contribution by extending risk management to the Microfinance sector to help us understand the risk management strategies used by MFIs in Cameroon. Our second contribution is increasing risk management literature by exploring the risks strategies used by MFIs in Cameroon. This paper will have important policy implications as it will mean putting in place framework consistent with the demands of the MFIs sector in Cameroon given the unique background of Cameroon.

Understanding the risk management strategies used by MFIs in the case of Cameroon is unique and important because, historically, Cameroon has had different colonial rule, starting with the Germans between 1884 and 1914. After World War I, Cameroon became a mandated trustee territory of the League of Nations between 1914 and 1922 and thereafter was partitioned between France and Great Britain who controlled Cameroon as separate territories until January 1, 1960 when French (East) Cameroon had her independence and October 1, 1961 for British Southern (West) Cameroons (Ardener, 1962). In terms of accounting standards, there has been distinctive changes of accounting standards in Cameroon based on long established French traditions (Elad, 2015). The accounting system of Cameroon according to Elad (2015) has been highly entrenched with colonial rule; starting the PCG (Plan Comptable General) under the French rule, to OCAM (Organisation Commune des Afrique et Madagascar) in 1974 to OHADA (The Harmonisation of Business Laws in Africa) in 1998. Present day OHADA accounting plan is a blend of the AngloAmerican approach with the French uniform accounting model by codifying some of the provisions of IFRS, and incorporating them as numbered articles within its framework, in line with the civil law tradition wherein codes and statutes are highly structured and systematised (Elad \& Tumnde, 2009). The OHADA Accounting plan was extended to cover MFIs in Cameroon in 2012. With all this confusion and changes in nomenclature, in order to help meet their objectives, managers of MFIs in Cameroon price risk differently (Nocco \& Stulz, 2006).

According to McGoun (1995), our understanding of risk is important because it is a measure of our expectations. He argued that if we cannot measure risk, then we cannot measure the 
value of our asset. Unfortunately, our understanding of risk has been overshadowed by our risk appetite (Power, 2005) as this in most cases is controlled by the choices and gambling habits of managers (March \& Shapira, 1987). This has seen our risk appetite either expressed through society where regulators act to enforce the rule of law or through managers who act in the interest of the organisation in pursuit of economic gains.

The aim of this paper is to identify the different type of risks that MFIs are exposed to, and to show how MFIs managers in Cameroon manage these risks so as to mitigate their effects on their social and financial objectives. Through this research, we will contribute to risk management research by proposing innovative risk management practices, that will allow managers of MFIs to be more proactive and self-regulate rather than having to wait for some external reviewer to point out the problems and risks they face. This will help in avoiding the situation where "regulators are left analysing the wreckage only after a bank has had a financial crisis" (Steinwand, 2000: 5). In order to help us achieve these aims, this research is based on 15 in-depth interviews with managers and lending officers of MFIs affiliated to the Cameroon Cooperative Credit Union League (CamCCUL) Limited. So as to better understand risk and how they are managed by MFIs, this paper is structured as follows; the next section looks at a brief background of our case study, followed by literature review. In the third section, we present our research methodology, the fourth is our data analysis and discussion and the fifth section is our summary and conclusion.

\subsection{Background to study: CamCCUL}

Formed in 1968, CamCCUL is an umbrella organisation made up of 208 affiliated MFIs. Following the reorganisation of the microfinance industry and with the implementation of law number 92/006 of August 14, 1992 restructuring Cooperative societies operating in Cameroon, CamCCUL re-registered with the Banking Commission of Central Africa (COBAC) on February 10, 1994. It is worth mentioning here that as per the 1994 laws on Cooperatives in Cameroon, all MFIs affiliated to CamCCUL are classified as category one MFIs (Akanga, 2016). Category one MFIs in Cameroon following COBAC regulations, can collect savings and grant loans to members only. For a full discussion of MFI categorisation in Cameroon, see Akanga (2016). This restructuring was following a period of uncertainty in the late 1980s where most MFIs were considered as have reached financial self-sufficiency, were competing amongst themselves and for customers (Zeller \& Meyer, 2002). This resulted to huge debts and losses within the sector. COBAC being an organisation in charge of regulating banking activities within the Monetary Union of Central African States (CEMAC), was called in to regulate the microfinance sector (Akanga, 2016). As of December 
2014, CamCCUL reported total assets of USD 306 million and a gross loan portfolio of USD 188 million outstanding to 81,000 borrowers. As of the same date, the organization reported USD 240 million in deposits held for 300,000 depositors.

CamCCUL offers a series of services to affiliated MFIs. These services are not limited to risk management, training and education, gender sensitisation, audits, representation and consultancy. These services are mostly for the top management of these MFIs. However, each MFI is allowed to provide training and education to its staff on these areas as they are seen as having a long-term effect on the financial sustainability of the MFI (Zeller \& Meyer, 2002).

\section{Literature review}

\subsection{Microfinance and risk}

There is no universally accepted definition of risk and risk management; the reason being different approaches that have been used to characterise risk (Aven \& Renn, 2009). Risk has been defined as a measurement of the probability of the outcome of events (Lowrance, 1976, Graham \& Weiner, 1995); or as consequences of certain expected outcomes (Kaplan \& Garrick, 1981); or as a result of some human action and for which the outcome is uncertain (Rosa, 2003). As a result of the lack of any definition, risk and risk management has become highly problematic to management of financial institutions, investors, regulators and auditors (Sikka, 2009, Mikes, 2011).

In this paper, we draw from the different characterisation of risk (Aven \& Renn, 2009) and look at risk as the possibility where an adverse event can occur and thus have negative implications for MFIs. In our case, we consider risk to be a "calculative culture" involving a mixture of social ideals and mathematical approximation (Mikes, 2009). We also look at Risk management as the process of managing these adverse events to acceptable range or limits as set by the MFIs (Steinwand, 2000). Our approach to risk management is said to be revolutionary (Harney, 2010) as it considers lessons learned from the financial crisis that began in 2007 and added incremental aspects that could not be counted to make us better understand and manage risk (Taleb, et al., 2009).

Steinwand (2000) identifies three major categories of risks faced by MFls; financial, operational and strategic risks. The financial risks stem from the breakdown of the Bretton Woods agreement in 1972 which has resulted in changes in the financial environment such as increase volatility in foreign exchange rates, interest rates and increase commodity prices (Smith et al., 1989). Smith et al., (1989) argue that, saving and loan schemes such as MFIs 
are often the subject to changes in interest rate risk. They are hardest hit because they fund long term assets such as loans to contractors with liabilities that are frequently repriced. As a result, whenever there is any rise in interest rates, the value of their assets declines significantly and consequently, the value of the equity for their shareholders. On the other hand, Oluyombo \& Olabisi (2008) suggest that, the greatest risk faced by MFIs is liquidity risk. Most MFIs depend on NGOs for survival. This has led to microfinance advocates coming up with the "win-win" proposition by which MFIs with good banking principles will be those considered to have contributed most to poverty alleviation (Morduch, 2000). Morduch (2000), however, argues that this proposition has not been followed by logic as most MFIs are still dependent on NGOs and any attempt by NGOs to withdraw or suspend their financial support to these MFIs will threaten their financial base (Oluyombo \& Olabisi, 2008). To Oluyombo \& Olabisi (2008), most MFls still heavily rely on funds from the state and NGOs and any change on their finding sources will not only reduce the funds available to them but will pose a serious liquidity risk to them.

Another area of financial risk concern for MFIs is credit risk (Hulme \& Mosley, 1996). Credit risks faced by MFIs does not only include non-repayment of loans, but also concern loan applications that have been turned down as this may have an effect on the growth of MFIs, their earnings and profitability (Oluyombo \& Olabisi, 2008). So as to minimise these problems, MFIs have spun a number of innovative programmes such as joint liability contracts which have seen a high loan repayment rate (Kono and Takahashi, 2010). To Kano and Takahashi (2010), through the joint liability contract, MFIs have been able to bypass the selection, moral hazard and information asymmetry problems and increase repayment rates. However, Ibtissem \& Bouri (2013:12) argue that MFIs have been able to use other methods such as "non-refinancing threats, regular repayment schedules, collateral substitutes, and the provision of nonfinancial services" to increase loan repayment rates.

Operational risk has also been identified as another area of concern for most MFIs (Steinwand (2000). Steinwand (2000: 17) argue that operational risk relates to "the potential that inadequate technology and information systems, operational problems, insufficient human resources or breaches of integrity will result to losses". Steinwand (2000) identifies transaction and portfolio risks as being the most source of operational risk for MFls. They argue that, MFIs that handle high volume of small transactions are more prone to transaction risks. This is because, in most cases, MFI staffs are not well trained to handle such high volume small transactions (Armendariz \& Szafarz, 2011). On the other hand, Steinwand (2000) argues that, portfolio risks account for a bulk of operational risk. This risk results from 
MFIs offering additional financial products such as savings and insurance in addition to their Ioan portfolio.

Strategic risk in the form of governance is another potential risk for MFIs. This is risk associated with poor governance (Akanga, 2016). However, to protect against this governance issue, most MFIs have started to get a mix of people with different skills and backgrounds on their boards (Bakker et al., 2014). This also protects the MFI from any form of negative publicity relating to their sources of capital and earnings that can affect them selling their products and services (Steinwand, 2000). According to Steinwand (2000), this has seen MFIs handle with care their reputation and is now more concern with risks management frameworks that will allow them strengthen their reputation with customers, their funders, investors and regulators.

In the context of Cameroon, it is not clear whether all of these risks may be of importance to MFIs. Therefore, our study seeks to contribute to risk management literature by identifying which of these risks are relevant and how managers manage these risks.

\subsection{Theoretical framework}

This research combines both the theories of positive accounting thought (Watts \& Zimmerman, 1978) and the social construction of positive choices (Neu, 1992). The aim of this paper is to identify the different type of risks that MFIs are exposed to, and to empirically show how MFIs managers in Cameroon manage these risks so as to mitigate their effects on their social and financial objectives and then propose innovative risk management approaches that can be applied within the sector. By combining these two theories, it is possible to look at how managers are "resourceful and innovative" in their risk management approaches with the aim of maximising their economic utility (Watts \& Zimmerman, 1978) and also bring in the social construction perspective to show how agents and institutions influence the manager's decisions and choices (Neu, 1992).

Watts and Zimmerman (1978: 131) argue that, managers risk appetite is a result of their "self-interest" all with the hope of maximising their utility (Gordon, 1964). They argue that a manager's decisions and behaviour are based on economic rationale where these managers believe that they function in markets where there is no "prolonged human or social contract among or between parties" (Granovetter, 1985: 484). So as to maximise their utility, managers go extra lengths to take on risks especially as their wages are a function of how 
much profits they make for their organisation (Rajgopal \& Shevlin, 2002). On the other hand, Neu (1992: 225) argues that not only economic factors "influence, constrain and define" the choices that managers make. They argue that "individual, institutional and social" interactions should also be considered when trying to understand the risk choices and behaviour of managers.

At the individual level, managers have developed certain personal relationships within societies which they operate. This helps them expand the scope of factors they consider when making any risk decisions as they will have an effect on the societies they operate in and their services. As a result, certain risks taken by managers have become the norm and become accepted over time (Zucker 1986 \& Powell 1988). Neu (1992: 226) argues, these norms have become expectations and "override what would appear to be the economically correct decision in the absence of such relations". On the other hand, even though personal factors expand on the scope of risk making areas, normative factors have a great influence on the behaviour and risk appetite of our managers as this helps them identify the different risk areas and the possible solutions to mitigate the possible outcomes of their risk taking (DiMaggio \& Power, 1993, Neu, 1992).

Another area affecting the decisions of managers of MFIs is institutional relationships (Neu, 1992). These institutional level relations are resources dependency through which external parties whom these MFIs are dependent on influences the managerial choices of MFIs managers by controlling the resources available to them (Pfeffer \& Salancik, 1978; Neu, 1992). By controlling the resources made available to MFIs, these third parties can influence the risk appetite of the MFIs managers (Scott, 1987). Scott (1987) argues that, shareholders as has become the norm in most shareholder owned MFIs, can control the risk appetite of their managers through an increase in demand for profitability. By controlling the capital made available to MFI managers, this can push MFI managers to increase their risk taking in a bid to make these huge profits (Kyereboach-Coleman, 2007). In a more indirect relationship as resources dependency, Neu (1992) argues that institutions also have an effect on the choices made by managers. This influence in most cases comes in the form of changes in accounting regulations (Watts \& Zimmerman, 1990).

\subsection{Prior studies on MFI risk management strategies}

Much research on risk and risk mitigation by MFIs has been on joint liability contracts. Morduch (1999) argue that joint liability contracts do mitigate portfolio risks for MFIs by reducing the adverse selection and moral hazard problem, providing group dynamic incentives, improved regular loan repayment programmes especially as future loans are 
lagged on repayment, and provides a collateral substitute as group members monitor each other (Brau and Woller, 2004).

Several other studies around MFI risk are mostly on how to manage portfolio risk. Crabb \& Keller (2006) carried out a cross sectional research using data from 37 international MFIs and concluded that MFIs should continue to explore the use of both individual and joint liability contracts. They argue that even though managers want to maximise their economic utility through individual liability contracts, joint liability contracts help to mitigate portfolio risk. To Wydick (1999), through joint liability contracts, MFIs reduce their monitoring cost but see an increase loan repayment. The increase in loan repayments is as a result of participants being able to monitor each other and enforce group relationships (Crabb \& Keller, 2006). Zeller (1998) in a similar research looking at the effects of group lending on portfolio risk using a random sample from 146 lending groups in Madagascar concluded that joint liability contracts mitigates risk for MFIs where group participants face the same risks. Portfolio risk is mitigated in such instances through an increase in loan repayment rates (Zeller, 1998).

Woller, (2000) studied the relationship between return and portfolio risk using data from nine village banking institutions and concluded that the interest rate on loans affects the size of the loan and the type of borrower. His findings are consistent with Madajewicz (2011) who argued that MFI managers choose to maximise their economic gain by selecting risky borrower who is ready to take out huge loans and thus will prefer individual liability contract over joint liability contract.

However, joint liability contracts have not been popular as widely anticipated. The reason why joint liability contracts still remain unpopular is because of their effect on borrowers (Madajewicz, 2011). Madajewicz (2011) in a study to find out which between joint liability and individual liability contract offers the borrower the most economic utility, concluded that wealthier borrowers prefer individual liability contracts because of the greatest return. On the other hand, she argued that MFIs prefer joint liability contracts because they reduce their monitoring costs. As a result, poor borrowers are forced to take out joint liability contracts to invest in small business because their loan sizes are small and consequently and their returns are small compared to rich borrowers (Jensen, 1969). The whole notion of joint or individual liability contracts is to promote investment amongst borrowers. As Jensen (1969) argues, the level of return is a correlation of the level of risk taken by the manager. Most managers of shareholder MFIs are out to maximise their economic utility. Jensen (1969) and Madajewicz (2011) argue that, for a manager of an MFI to maximise this economic utility 
while creating wealth for the shareholders (Akanga, 2016), they have to choose a borrower with risky project with the aim of offering huge loans.

Despite these studies looking at risk and risk management strategies used by MFIs, Morduch (1999) argue that empirical evidence is required to help us understand the sensitivity of risk on MFI activities. Previous studies have been based on desktop research and narrowly on just one (portfolio risk) of the many risks faced by MFIs institutions (Crabb \& Keller, 2006). In our case, we are looking at all the different types of risks that MFIs face from the managers' perspective and understand how they manage these risks. Through our research, we intend to achieve the "Microfinance promise" of "experimentation, innovation and evaluation" (Morduch, 1999: 1572) and make contribution through empirical research on the different types of risks faced by MFIs.

\section{Research Methodology}

This research is based on 15 in-depth interviews with managers and lending officers of 8 MFIs within CamCCUL network conducted in June 2016. The interviews range between 45 minutes to 1 hour. Interviews were conducted with managers and lending officers in their offices. The interviewer role was to direct the interview process using an interview guide. The interviewer followed up answers where more clarification was needed with a question. This allowed the managers and lending officers to freely express themselves. The managers and lending officers were selected from $23 \mathrm{MFI}$ personnel (10 managers and 13 lending officers) who agreed to a request sent to them by the interviewer. Of the 23 who agreed, 15 (7 managers and 8 lending officers) respondents from 8 MFIs were selected based on purposive random sampling. The selected sampled was based on the criteria that the manager must have been working within the microfinance industry for a minimum of 15 years and 10 for the lending officer.

The following table gives a distribution of respondents. For confidentiality, all names of MFIs, managers and lending officers have been disguised

\begin{tabular}{|l|l|l|l|}
\hline Serial $\mathrm{N}^{\circ}$ & \multicolumn{1}{|c|}{ Name of MFI } & \multicolumn{1}{|c|}{ Name of Manager } & Name of lending officer \\
\hline 1 & A & Elizabeth & Sampson \\
\hline 2 & B & Victor & Joana \\
\hline 3 & C & Peter & Daniel \\
\hline 4 & D & Paul & Joshua \\
\hline 5 & E & John & Titus \\
\hline 6 & F & Susan & Dickson \\
\hline 7 & G & Simon & Henry \\
\hline 8 & H & & Juliette \\
\hline
\end{tabular}


The questions allowed managers to discuss about risk from their perspective, how they define risk and those factors they take into account when coming up with risk definition. Managers were asked to discuss the most risks they face as an institution, if at all there are any risks they find different from their previous experiences working with other MFIs. They were also asked to discuss how they have managed the risks they face and if the strategies are written down in certain manuals or they manage these risks as they go along. They were also asked to compare the risk management strategy of their MFI in relation with their previous positions. In order to help us better understand the risk management strategies from their previous experiences, they were asked to compare the different strategies they have used and make an evaluation as which provides them the best method of risk mitigation.

Purposive random sampling was used to select respondents because it involves selecting respondents "based on a specific purpose rather than randomly" (Tashakkori \& Teddlie, 2003, p. 713). The aim of our research is to identify the different risks that MFI managers face and how they mitigate them and then propose an innovative risk management strategy. To do so, purposive random sampling is best as it allows the researcher gets an in-depth study of risks within MFls and those issues central to risks management (Patton, 1990) by purposefully selecting respondents who have worked for a certain time within MFIs. By purposefully selecting managers and lending officers with this number of years of experience, we are creating a small sample with great variety. Patton (1990: 172) argues that findings from studies of this type of sampling yield "high-quality, detailed descriptions of each case, which are useful for documenting uniqueness and important shared patterns that cut across cases and derive their significance from having emerged out of heterogeneity".

The research method used is multiple case study approach. Case study allows the researcher the possibility to investigate contemporary phenomenon whose boundaries are not evidently clear within its real-life context (Yin, 2009). Case study research method allows us the possibility to investigate phenomenon and look at the world around us by using multiple data sources such as interviews, document review and observations (Silverman, 2013). Case study research method offers the researcher the possibility to investigate phenomenon that might not be achieved if other research methods are used. The greatest advantage of case study research method over other research methods is with the use of large amount of data and observations. It serves as a useful tool for the preliminary, exploratory stage of a research project, and is well suited to research areas for which existing theory seems inadequate (Eisenhardt, 1989). Case study can either be single or multiple case study approach. Multiple case study method involves studying multiple sites. 
By using the multiple case study approach in research, this increases the scope of the investigation and this provides us with the potential for generalising our findings due to the triangulation of evidence (Eisenhardt 1989, Miles \& Huberman, 1994, \& Patton, 2002).

We adopted this multiple case study approach to permit us interview multiple managers and lending officers of multiple MFIs at different sites. This method will allow us identify the different risks that MFI managers face and how they mitigate them, then propose an innovative risk management strategy that can be implemented across different MFIs in Cameroon and generalised in other countries. To achieve this, the multiple case study approach will permit us capture any common patterns that emerge from this great variation of managers interviewed that are of particular interest and value (Patton, 1990). Patton (1990) argues that by using purposive random sampling, we are best placed to make use of the core experiences of these managers, in order to understand their risk appetite and the rationale for the choices they make and propose how to deal with the outcomes.

The data for this research was analysed using content analysis. Content analysis is a research method used in analysing written, verbal or visual communication messages and documents (Cole, 1988, Elo \& Kyngäs, 2007). Content analysis provides an objective means of describing and quantifying the issues under question (Krippendorff, 1980). Elo \& Kyngäs, (2007: 108) argue that by using content analysis, it is possible "to test theoretical issues to enhance understanding of the data......by distilling words into fewer content related categories". To Krippendorff (1980), content analysis provides the researcher with the opportunity to replicate and make valid inferences from data to the context thus providing knowledge, new insights, representation of facts and a practical guide to facts.

In our case, we classified words and phrases with similar meaning from our interviews into different categories. By classifying words and phrases from the interview into categories, we were able to condensed and broaden the risks that MFIs in Cameroon are exposed into different categories making it easy for us to describe the different risk strategies used by MFIs in Cameroon.

\section{Data analysis and discussion}

Risk management has become formalised within organisations (Miller et al., 2008) with the aim of putting in place framework that can help organisations overcome any eventuality. Within MFIs affiliated with the CamCCUL network, risk has been perceived and defined differently by different managers and lending officers. These differences in definition are the result of differences in characterisation as argued by Aven \& Renn (2009). Unlike Mikes 
(2009) who look at risk being consisting of certain mathematical models, the perception and definition of risk by managers of MFIs affiliated within the CamCCUL network is based on social constructs (Neu, 1999) and this has had an influence on their risk appetite.

The whole concept of microfinance in Cameroon to all the managers and lending officers interviewed, started "from a social construct better known in Cameroon as njangi's". Njangi's are an informal savings scheme through which people within a community come together, put together funds for members to benefit every month and on a rotatory basis (Akanga, 2016). This is a self-select membership group of individuals and requires no collateral and has existed in Cameron for generations and is still being widely practiced today. Based on this, all the managers and lending officers argue that "this has affected the way we look at risk and define risk". According to Victor (manager of MFI B), risk is "how my society looks at my actions and interactions". As Granovetter (1985) argue, this social "embeddedness" does not only affect the way these managers pursue economic gains for their organisations and maximise their economic utility (Watt \& Zimmerman, 1990), but also affect their risk choices and decisions (Neu, 1999). Simon (manager of MFI G), Daniel (lending officer for MFI C) and Dickson (lending officer for MFI F) argue that, they grew up in the communities where they are now managers and "know almost everyone by name". Elisabeth of MFI A and Susan of MFI F further argued that this affects the way they assess "the riskiness of clients" and how they "make certain decisions about MFI activities". According to Sampson (lending officer for MFI A), "by working in the environment which I grew up has had a bearing on the way I look at risk".

Reputational Risk has been identified by 5 managers of MFIs (A, D, E, F, \& G) as being of great concern to them. Reputational risk is regarded as being elusive and can cause a lot of damage to an organisation due to our inability to understand its origin and measure its effect on the organisation in the eyes of third parties (Perry \& De Fontnouvelle, 2005). According to Perry \& De Fontnouvelle (2005: 4), the effects of reputational risk on the organisation range from "the negative publicity about an organisations business practices, a decline in the customer base, costly litigation, or revenue reductions". For fear of damaging their reputation within their societies, managers of MFIs tend to pursue their economic gains gently because any harm to the organisation is often intangible and affect the organisation gradually ( $\mathrm{Neu}$, 1999 \& Perry \& De Fontnouvelle, 2005). Because managers of MFIs see risk as a social construct, they tend to act in all fairness (Neu, 1999). As Paul (manager of MFI D) argued, "we do not see our clients as being risky until proven otherwise". To Neu (1999: 227), "social and community norms appear to influence and constraint the behaviour" of most clients as delinquency can be sanctioned by the society. This sanction according to Henry (lending 
officer of MFI G) is often by means of "social exclusion". Henry further argues that "this therefore makes clients less risky to us". Through such social interactions, MFI managers have been able to gain legitimacy (DiMaggio \& Powell, 1983) thereby maximising the organisations economic life chances (Meyer \& Rowan, 1977).

Another risk of greatest concern to MFI managers in Cameroon is the death of a borrower. According to John (manager of MFI E), "our greatest problem is when a borrower dies without repaying their loan". This is a major cause for concern to MFI managers because of "societal expectations such as norms of fairness" (Neu, 1999: 227). According to Simon (manager of MFI G), "society expects us to show some empathy with a bereaved family in such situations". This has affected managers' decisions and choices on what would be an economic rational decision to demand for family and relations to repay the loan (Kahnemann et al., 1986). In such instances, Peter (manager of MFI C) argued that "he is left with hard decisions and choices as to the next cause of action". This situation according to Elizabeth (manager of MFI A), can have "long term effects on the MFI as it might affect not only the reputation of the manager", but also profits of the organisation in the long run (Kahnemann et al., 1986). According to Joana (lending officer for MFI B), the risk of the death of a borrower can have effects on the financial, operational and strategic management of the MFI as clients who think they have been treated unfairly by the MFI "often start looking for alternatives". This has seen MFIs investing on their reputation so as to produce goodwill to redeem their reputation in front of any disgruntled customers and society (Kahnemann et al., 1986). The reason for this investment in reputation is to gain legitimacy as they become adopted by society as practices of good management (DiMaggio \& Powell, 1983).

Credit risk is another risk of concern to managers of MFIs in Cameroon. The main sources of Credit risk as identified by Qian \& Strahan (2007) and Njiskens and Wagner (2011) are poor governance, inappropriate regulation, limited institutional capacity, inappropriate bank credit policies, reckless lending practices, poor credit assessment, poor loan underwriting policies, poor lending practices, government interference and inadequate supervision. Credit risk is the main cause of the 2007 financial crisis (Nijskens \& Wagner, 2011). Njiskens and Wagner (2011) argue that, banks took advantage of the poor legislation and became reckless in the way they awarded loans. This resulted in a domino effect where if one creditor is unable to repay their loan, others follow suit. In a similar manner, according to Simon (manager of MFI $\mathrm{G})$, credit risk is important for MFIs in Cameroon because due to inappropriate supervision (Akanga, 2016), MFls managers "have become reckless in their lending practices all with the aim of making huge profits for their shareholders". According to Juliette (lending officer for MFI H), "our greatest source credit risk is with contractors and other big investors whose 
loans sizes are in value". According to Titus (lending officer of MFI E) "this has seen many MFIs lending officers do no credit assessment on clients". This situation is further compounded by managers and lending officers who in a bit to increase their economic utility (Watt \& Zimmermann, 1990), as Daniel (lending officer for MFI C) argued, are now "lending to customers based on social ties". This to Akanga (2016) is a result of poor legislation governing MFIs in Cameroon where the supervisory authority, the Ministry of Finance, does not have the institutional capacity to make sure that MFIs in Cameroon strictly comply with the regulations in place. Due to this uncertainty, designing any incentive plans for employees working with lending within MFIs with the hope of minimising this tendency for employees' lending to individuals with poor credit ratings is hard (Qian \& Strahan, 2007). According to Paul (manager of MFI D), "we do not have any statistics that guide us on the credit riskiness of borrowers" thus leaving managers to make credit decisions based on social relations by awarding loans at higher than market interest rates (Uzzi, 1999, Akanga, 2017). Because of lack of any credit ratings about clients, Joshua (lending officer of MFI D) argues that "we mitigate any risk through third party collateral". "Third party collateral" to Akanga (2017) refers to when a MFI uses the savings of another client as collateral for a loan awarded its client.

Another risk identified by MFI managers in Cameroon is their institutional size. According to Susan (manager of MFI F), "even though we all are affiliated to CamCCUL, our institutional sizes are different and this has effect on the type of customers we can attract". Bigger MFIs have lower operating cost, lower default rates and enjoys economies of scale in its operations (Kyereboach-Coleman, 2007). According to Victor (manager of MFI B), "if we have to compete with the bigger MFIs, this will increase our operating cost". This operating cost according to Dickson (lending officer for MFI F) is through "multiplying the number of field loan officers and more door to door campaigns". With increase in costs, Peter (manager of MFI C) argued, "this will push us to be more profit oriented at the expense of meeting our social objective". In a similar line of thought, Roberts (2013: 121) argue that institutional size is good for MFIs as this will allow managers to be more "commercial thinking and market discipline" and are better placed at reducing their costs through "share ideas, experiences, and innovative solutions to the challenges they face in search of continuous growth and progress".

\section{Summary and Concluding remarks}

In this paper, we have made contributions to both risk management literature and Microfinance sector by using empirical evidence from MFIs in Cameroon to show the 
different types of risks faced by MFIs and how these risks are managed. We have identified 4 major sources of risk concerns for MFIs operating in Cameroon; reputational risk, death of borrower, credit risk and risks associated with growth in size. These risks as in the 2007 financial crisis contributed to the turmoil witnessed thereafter. So as to avoid future turmoil and especially within MFIs, MFIs have had to shed their risks into the financial systems in different ways and if care is not taken, we are heading for another period of huge losses by MFIs (Zeller \& Meyer, 2002). Looking at the different risks, we are proposing risk management approaches that have been adopted by banks to minimise the impact of these risks on their social and financial sustainability.

Law number 92/006 of August 14, 1992 on Cooperatives societies (MFIs) operating in Cameroon has granted rights for category one MFIs to have shareholders. The aim is to allow these category one MFIs to broaden their reach and lend to the millions of poor borrowers who continue to remain without financial services (Paul, 2010). Unfortunately, this has not been accompanied by institutional provisions to support these MFIs as many are still dependent on a few individuals and donations from the state and NGOs (Paul, 2010). If our intention is to make sure that microfinance and MFIs meet their social objective while at the same time remain financially sustainable, we propose that MFIs have to break that cocoon and take the for-profit status. By taking the for-profit status, Paul (2010: 1392) argues that it is only then that MFIs will have "the kind of investors who are willing to lend capital because they can expect to profit from their investment". It is only by allowing MFIs to take the forprofit status that our managers will take those risks that will allow investors to measure the value of their assets (McGoun, 1995). Kyereboach-Coleman (2007) argue that if we allow MFIs to take the for-profit status, they will not only reach out on an increase number of the poor, but will also enjoy economies of scale, better placed to deal with the moral hazard and the adverse selection problem and can better deal with all those risks identified as being of greatest importance by MFI managers and lending officers in the case of Cameroon. By allowing MFIs to adopt the for-profit status, this will allow managers shed their risks in the financial system in the form of derivatives such as Credit Default Swaps (CDS) (Nijskens \& Wagner, 2011). Nijskens \& Wagner (2011: 1391) argue that CDS will allow MFIs managers to shed their "credit risk on a variety of exposures". By so doing, managers and lending officers will not have to worry about reputational risk, the risk if a borrower dies, credit risks and institutional risk as this will mean MFIs securitising their loans through Collaterised Loan Obligations (CLOs) and they can now shed loans to contractors and investors in the financial markets on a large scale (Nijskens \& Wagner, 2011). By being able to securitise their loans, 
this will give the MFIs the opportunity to benefit from economies of scale and thus reduce their costs through higher interest rates (Kyereboach-Coleman, 2007, Roberts, 2013).

Based on our findings, risk management will have implications on how governments design regulations to monitor and supervise MFIs (Kirkpatrick \& Maimbo, 2008). If MFIs will have to shed their risks into the financial markets in order to minimise their effect of the different risks identified, this means special regulatory and supervisory framework consistent with their activities and risks appetite. 


\section{References}

Ardener, E. (1962). The Political History of Cameroon. The World Today 18(8): 341 - 350

Akanga, F.K. (2016). Governance of microfinance institutions (MFIs) in Cameroon: what lessons can we learn? Enterprise development and Microfinance: An International Journal, 27(3): 219 - 235

Akanga, F.K. (2017). Microfinance accountability in Cameroon: a cure or a curse for poverty alleviation? Journal of Accounting and Organisational Change, 13(1): $112-130$

Akanga, F.K \& Roberts, D.A: Regulating Accounting practices within the Microfinance Industry; is it necessary? A critical analysis using the case of Cameroon, forthcoming.

Armendariz, B. \& Szafarz, A. (2011). On Mission Drift in Microfinance Institutions. The Handbook of Microfinance. London: World Scientific.

Aven T and Renn O (2009). On risk as an event where the outcome is uncertain. Journal of Risk Research 12 (1) 1-11

Bakker, A., Schaveling, J., \& Nijhof, A. (2014). Governance and Microfinance Institutions. Corporate Governance. 14(5): $637-652$

Beck, U. (1992): Risk Society - Towards a new modernity. London: Sage.

Berenbach, S., \& Chruchill, C. (1997). Regulation and supervision of Micrfinance Institutions: Experiences from latin America, Asia, and Africa. The Microfinance $\begin{array}{lllll}\text { Network Occasional } & \text { paper } & \text { No. } & 1 . & \text { [pdf] }\end{array}$

<https://pdfs.semanticscholar.org/fef0/69a32763b4cdd63405a319a51a9277e3c4d0.pdf> [Accessed 19 March, 2018]

Brau, J.C. \& Woller, G. M. (2004). "Microfinance; A comprehensive review of existing literature," Journal of Entrepreneurial Finance and Business Ventures, 9(1): 1 - 26

CGAP, (2001). Commercialisation and mission drift. The transformation of microfinance in Latin America. Occasional paper, January, Washington, DC: Consultative group to Assist the Poor.

CGAP, (2004). "Building inclusive financial systems. Donor guidelines on good practice in Microfinance", December, Washington, DC: Consultative group to Assist the Poor.

Christen, R.P., \& Drake, D. (2002). Commercialisation: The new reality of microfinance. In D. Drake, \& E Rhyne (Eds), The commercilisation of microfinance: Balancing business and development. Bloomfield: Kumarian Press 
Cole, F.L. (1988). Content Analysis: Process and application. Clinical Nurse Specialists 2(1): $53-57$

Copestake, J. (2007). "Mainstreaming Microfinance: Social Performance Management or Mission Drift?" World Development 35(10): 1721 - 1738

Crabb, P.R., \& Keller, T. (2006). "A test of Portfolio Risk in Microfinance Institutions", Faith and Economics, 47/48: 25 - 39

DiMaggio, P.J, \& Power, W.W, (1983). The iron cage revisited: Institutional isomorphism and collective rationality in organisational fields, American Sociological Review 48(2): 147 $-160$

Eisenhardt, K. M. (1989), "Building theories from case study research", Academy of Management Review, 14(4): 532 - 550.

Elad, C. (2015). The Development of Accounting in the Franc Zone Countries in Africa. The International Journal of Accounting, 50(1): 75 - 100.

Elad, C. \& Tumnde, M. (2009). Bookkeeping and the probative value of accounting records: Savary's legacy lingers on in the OHADA treaty states, International Journal of Critical Accounting, 1(1-2): 82-109.

Elo, S. \& Kyngäs, H. (2008). The Qualitative content analysis process. Journal of Advanced Nursing 62(1): $107-115$

Graham, J.D., \& Weiner, J.B, (1995). Risk versus risk: Tradeoffs in protecting health and the environment. Cambridge: Harvard University Press.

Granovetter, M., (1985). Economic action and social structure: The problem of embeddedness. American Journal of Sociology, 91(3): 481 - 510

Goldberg, M., \& Palladini, E., (2010). Managing Risk and Creating value with Microfinance, The World Bank, Washington DC.

Gordon, M.J., (1964). Postulates, Principles and Research in Accounting. The Accounting Review, 39(2): 251 - 263

Harney, S., (2010). Accounting, risk and revolution. Critical Perspectives on Accounting. 21(1): $14-17$

Hermes, N., Lensink, R., \& Meeters, A (2011). "Outreach and Efficiency of Microfinance Institutions", World Development, 36(6): 938 - 948

Hulme, D. \& Mosley, P. (1996). Finance against poverty, London, Routledge

Ibtissem, B. \& Bouri, A. (2013). Credit Risk Management in Microfinance: The conceptual Framework. ACRN Journal of Finance and Risk Perspectives, 2(1): 9 - 24 
Jensen, M.C. (1969). Risks, the pricing of capital assets, and the evaluation of investment portfolio. Journal of Business, 42(2): $167-247$

Kahnemann, D., Knetsch, J.L., \& Thaler, R., (1986). Fairness as a constraint on profit seeking: Entitlements in the market. The American Economic Review 76(4): $728-741$

Kaplan, S., \& Garrick, B.J., (1981). On the quantitative definition of risk. Risk Analysis 1(1) $11-27$

Kirkpaatrick, C., \& Maimbo, S.M. (2008). The Implications of the Evolving Microfinance Agenda for Regulatory and Supervisory Policy. Development Policy Review, 20(3): $293-304$

Kono, H., Takahashi, K. (2010). Microfinance Revolution: Its Effects, Innovations, and Challenges. Developing Economies, 48(1): 15-73

Krippendorff, K. (1980). Content analysis: An introduction to its methodology. Sage Publications, Newbury Park.

Kyereboach-Coleman, A., (2007). The impact of capital structure on the performance of microfinance institutions. The Journal of Risk Finance, 8(1): $56-71$

Lowrance, W. (1976). Of acceptable risk - science and the determination of safety. Los Altos, CA: William Kaufmann Inc.

Madajewicz, M. (2011). Joint Liability versus individual liability in credit contracts. Journal of Economic Behaviour \& Organisations, 77(2): $107-123$

March, J. \& Shapira, Z. (1987). Managerial perspectives on Risk and Risk taking. Management Science, 33(11); 1404 - 1418

McGoun, E.G. (1995). The History of risk "measurement". Critical Perspectives on Accounting 6(6): 511 - 532

Meyer, J. \& Rowan, B., (1977). Institutionalised Organisations: Formal Structure as Myth and Ceremony, American Journal of Sociology, 83(2): 340 - 363

Mikes, A., (2009). Risk management and calculative cultures. Management Accounting Research 20 (2009) 18-40

Mikes, A., (2011). From counting risk to making risk count: Boundary-work in risk management. Accounting Organization and Society 36(4-5): 226 - 245

Miles, M.B. and A.M. Huberman, (1994), Qualitative data analysis: An Expanded 
Sourcebook of New Methods, 2nd Edition, Sage, Thousand Oaks.

Miller, P., Kurunmaki, L., \& O'Leary, T. (2008). Accounting, hybrids and the management of risk. Accounting, Organizations and Society 33(7/8): 942 - 967

Morduch, J (1999). The Microfinance promise. Journal of Economic Literature, 37(4): 1569 1614

Morduch, J (2000). The Microfinance Schism. World Development, 28(4): 617 - 629

Morduch, J. \& Haley, B. (2002). Analysis of the effects of microfinance on poverty reduction. NYU Wagner Working Paper No. 1014: Issued June 28, 2002

Neu, D. (1992). The Social Construction of Positive choices. Accounting, Organizations and Society 17 (3/4): $223-237$

Nijskens, R. \& Wagner, W. (2011). Credit risk transfer activities and systemic risk: how banks became less risky individually but posed greater risks to the financial system at the same time. Journal of Banking and Finance, 35(6): 1391 - 1398

Nocco, B.W., Stulz, R.M. (2006). Enterprise Risk Management: Theory and Practice. Journal of Applied Corporate Finance, 8(4): 8 - 20

Oluyombo, O.O. \& Olabisi, J.B., (2008). Risk management in Microfinance Institutions, Journal of Applied Economics, 191): $104-112$

Patton, M. Q. (1990). Qualitative evaluation and research methods, 2nd Edition, Thousand Oaks, CA: Sage Publications.

Patton, M. Q. (2002). Qualitative Research and Evaluation Methods, 3rd Edition, Thousand Oaks, CA: Sage Publication.

Paul, M.S. (2010). Bridging the gap to the microfinance promise: a proposal for a taxexempt microfinance hybrid entity, New York University Journal of International Law and Politics, 42(4): $1383-2010$.

Perry, J., \& De Fontnouvelle, P. (2005). Measuring Reputational Risk: The Market Reaction to Operational Loss Announcements.

Available at SSRN: https://ssrn.com/abstract=861364 [Accessed April 5, 2018]

Pfeffer, J., \& Salancik, C., (1978). Control of organisations: A resource dependent perspective, New York: Harper \& Row

Powell, W., (1988). Institutional Effects on Organisational structure. (Ed). Institutional Patterns and organisations. Cambridge, MA: Ballinger

Power, M., (2009). The risk management of nothing. Accounting, Organizations and Society $34(6-7): 849-855$ 
Qian, J., \& Strahan, P.E., (2007). How laws and institutions shape financial contracts: The case of bank loans. Journal of Banking and Finance, 62(6): 2803 - 2834

Rajgopal, S. \& Shevlin, T. (2002). Empirical evidence on the relation between stock option compensation and risk taking. Journal of Accounting and Economics, 33(2): 145 171

Robinson, M.S. (2001). The Microfinance Revolution: Sustainable Finance for the poor, Washington D.C: World Bank Publications

Roberts, P.W. (2013). The profit orientation of Microfinance Institutions and effective interest rates, World Development, 41: 120 - 131

Rosa, E.A., (2003). The logical structure of the social amplification of risk framework (SARF): Metatheoretical foundation and policy implications. In The social amplifications of Risk, ed. Pidegeon, N., Kaspersen, R.E., Slovic, P. Cambridge: Cambridge University Press.

Scott, R. (1987). The adolescence of Institutional Theory. Administrative Quarterly, 32(4): $493-511$

Seibel, H.D. (2003). "History matters in Microfinance", Small Enterprise Development - An International Journal of Microfinance and Business Development, 14(2): 10 - 12

Sikka P (2009) Financial crisis and the silence of the auditors. Accounting, Organizations and Society 34 (6) $868-873$

Silverman, D. (2013). Doing Qualitative Research: A Practical Handbook, 4th Edition, London, Sage Publication.

Smith, C.W., Smithson, C.W., \& Wilford, D.S., (1989). Managing Financial Risk, Journal of Applied Corporate Finance, 1(4): $27-48$

Steinwand, D. (2000). "A Risk management Framework for Microfinance Institutions", Financial Systems Development and Banking Services, Eschborn, Germany

Taleb, N.N., Goldstein, D.G., \& Spitznagel, M.W., (2009). The six mistakes executives make in risk management. Harvard Business Review, 87(10): 78 - 81

Tashakkori, A., \& Teddlie, C. (Eds.). (2003). Handbook of mixed methods in social \& behavioural research. Thousand Oaks, CA: Sage.

Uzzi, B. (1999). Embeddedness in the making of financial capital: How social relations and networks benefit firms seeking financing, American Sociological Review 64(4): 481 - 505 
Watts, R. L., \& Zimmerman, J.L., (1990). Positive Accounting theory: A ten-year perspective. The Accounting Review, 65(1): 131 - 156

Watts, R.L., \& Zimmerman, J.L., (1978). Towards a positive theory of the determination of accounting standards. The Accounting Review, 53(1): 112 - 134

Wydick, W.B (1999). Can social cohesion be harnessed to repair market failures? Evidence from group lending in Guatemala." The Economic Journal. 109(457): $463-475$

Yin, R.K (2009). Case Study Research: Design and Methods. 4th Edition: London, Sage Publications

Zeller, M (1998). Determinants of repayment performance in credit groups: The role of programme design, intragroup risk pooling, and social cohesion in Madagascar. Economic Development and Cultural Change. 46(3): 599 - 621

Zeller, M., \& Meyer, R.L., (2002). The triangle of Microfinance: Financial sustainability, outreach, and impact. London, John Hopkins University Press

Zucker, L. (1986). Production of Trust: Institutional sources of economic structure, 1840 - 1920, Research in Organisational Behaviour, 8: 53 - 111 


\section{Appendix}

Interview Guide

1. Greetings

2. How long have you been working within the MFI industry?

- Same MFI and previous roles

3. Talk us through the state of the microfinance Industry in Cameroon: From its origin to date

4. What is your perception of risk? How would you define risk?

5. Based on your experiences, what are those risks facing the microfinance industry in Cameroon?

6. Which of these risks do you consider to be of importance to you when making lending decisions?

7. How do you manage these risks? What is the strategy put in place by your MFI to help you manage these risks?

8. How do you assess the riskiness of your clients? What factors do you take into account before awarding loans to your clients?

9. Talk us through any manuals or frame works that guide your risk analysis of your clients

10. How can you compare the risk assessment between your present and previous employers? 